\title{
Human and clinical perspectives on leptin
}

\author{
Werner F. Blum ${ }^{1,2 *}$, Piera Englaro', Andrea M. Attanasio ${ }^{2}$, Wieland Kiess ${ }^{3}$ and Wolfgang Rascher ${ }^{1}$ \\ ${ }^{1}$ University Children's Hospital, Giessen, Germany \\ ${ }^{2}$ Lilly Deutschland GmbH, Saalburgstr. 153, D-61350 Bad Homburg, Germany \\ ${ }^{3}$ University Children's Hospital, Leipzig, Germany
}

Body-weight regulation has for a long time been considered to be mainly a question of 'to eat or not to eat', subject to free will. However, a simple calculation sheds doubt on this view; a normal weight person of 60 years has ingested about $230 \times 10^{6} \mathrm{~kJ}$ during his life and, based on thermodynamics, has consumed exactly the same amount of energy, disregarding the amount of chemical energy stored during body growth in early life. If the daily energy intake had exceeded the energy expenditure by only $2 \%$, which is not more than a good mouthful of milk, this person would weigh about $200 \mathrm{~kg}$ today. If the daily energy intake had been $1 \%$ less than the expenditure, this person would have starved to death many years ago. This simple consideration suggests that body-weight regulation must be subject to mechanisms which balance the energy influx and efflux in an extremely fine-tuned manner.

The search for such mechanisms started about 40 years ago in the 'golden era of physiology', using parabiosis experiments in rodents. These led to the conclusion that a humoral factor must exist which is produced by adipose tissue and which is pivotal for the regulation of body weight (Kennedy, 1953; Hausberger, 1958; Hervey, 1959; Coleman \& Hummel, 1969). However, the most straightforward approach to the isolation and characterization of this factor by biochemical techniques failed. Solving this problem could be achieved only recently using modern techniques of molecular genetics, when J. Friedman and his collaborators (Zhang et al. 1994) cloned the gene from $o b / o b$ mice. Subsequently, the gene was cloned and expressed by a number of groups, and the gene product, which was termed 'leptin', referring to the Greek word leptós meaning thin (Halaas et al. 1995), became available for animal and human studies. During this short time, the knowledge regarding this new hormone 'exploded' in the real sense of the word. From animal experiments it became evident that leptin is not only pivotal for the regulation of body weight, but that it is also an integral component of various endocrine axes or, more correctly, of various endocrine feedback loops (Ahima et al. 1996; Barash et al. 1996; Chehab et al. 1996, 1997). Teleologically, this makes sense; the information on available energy stores provided by leptin is extremely important for the organism with respect to many key functions, such as maintenance of body weight, reproduction or growth.
The availability of recombinant human leptin (Lilly Research Laboratories) enabled us to develop a highlysensitive, accurate and robust radioimmunoassay to study serum leptin in human subjects (Blum et al. 1997a). Most importantly, the high sensitivity of the assay also allowed us to measure leptin precisely and accurately in patients and healthy individuals with low levels, such as very lean patients, young children or adolescent males. The current project to measure leptin levels in healthy subjects and in patients with diverse disorders had the following aims:

to define major controlling variables in human subjects; to construct reference ranges with respect to these major variables;

to investigate the regulation of circulating leptin in comparison with animal and in vitro experiments;

to search for pathological situations in which abnormal leptin production may possibly play a causal role.

Since studies in human subjects rarely allow wellcontrolled manipulations to the same extent as in animal experiments and, in contrast to in vitro experiments, always consider a most complex in vivo situation where many variables may interact, their potency to prove cause-effect relationships is limited. Any associations found must be examined, therefore, in terms of whether they are consistent with hypotheses derived from animal studies and in vitro experiments. This dual and complementary approach may then lead to theories on how leptin is regulated and how it acts in human subjects. On this basis, any role for leptin in the pathophysiology of disease states, such as obesity, eating disorders or infertility, may finally be derived.

\section{Constitutive variables controlling serum leptin: fat mass and androgens}

When we studied serum leptin levels in large cohorts of healthy children, adolescents and adults (about 2000 individuals), it became evident that body fat is the major determinant of circulating leptin. This observation has also been made by many other groups (Considine et al. 1996; Horn et al. 1996; Blum et al. 1997a) and is consistent with findings in rodents (Frederich et al. 1995; Maffei et al. 1995; Considine et al. 1996). It is not surprising that adipose tissue is the main source of leptin. The relationship between leptin levels

Abbreviations: GH, growth hormone; IGF-1, insulin-like growth factor-1.

*Corresponding author: Dr Werner F. Blum, fax +496172 273 427, email Blum_Werner@Lilly.com 
and measures of body fat mass, such as BMI and percentage body fat (determined by bioelectric impedance measurements or by dual energy X-ray absorptiometry), revealed an exponential characteristic, indicating that small changes in body fat result in relatively large changes in serum leptin (Blum et al. 1997a) and explaining the tremendous variation in leptin levels of over three orders of magnitude.

During sexual maturation, a divergent pattern has been observed in both sexes (Fig. 1). While in girls leptin levels increased steadily with pubertal development, the levels were highest in boys during early puberty (Tanner stage 2; Tanner \& Whitehouse, 1976) and declined thereafter, resulting in about 8-fold higher leptin levels in females compared with males at Tanner stage 5, although BMI values were comparable (Blum et al. 1997a; Clayton et al. 1997). From animal studies in rodents it has become clear that leptin plays a key role in allowing puberty to proceed (Ahima et al. 1997; Chehab et al. 1997; Cheung et al. 1997; Pierroz et al. 1997). It may be hypothesized, therefore, that leptin has a permissive role in relation to pubertal development in human subjects also, although it is hard to conceive that leptin per se triggers puberty (Mantzoros et al. 1997). This finding provides an explanation for the hypothesis of Frisch (1980), known to paediatricians for a long time, that a critical fat mass is required for puberty to occur.

A sex-specific pattern was also established, with leptin levels being related to BMI. While the exponential regression lines for leptin $v$. BMI in both sexes were almost identical at Tanner stages 1 and 2, there was a marked decline in boys at a given BMI value during further progression of puberty. This decline was much less pronounced in girls (Blum et al. 1997a). To exclude the possibility that the divergent developmental pattern of body composition, with males increasing their BMI during puberty mainly through an increase of muscle mass and girls mainly through accumulation of fat mass, is the cause of this phenomenon, leptin levels were also related to body fat determined by bioelectric impedance measurements. However, a significant sex difference remained (Blum et al. 1997a), suggesting the presence of a sex-specific regulator other than fat mass.

In large cohorts of healthy adults of both sexes (more than 1200 ) between 20 and 80 years of age, a clear sex difference was obvious, with higher levels in females even after adjustment for BMI, in accordance with reports by others (Hickey et al. 1996; Horn et al. 1996; Ma et al. 1996; Saad et al. 1997). However, in adults, age did not significantly contribute to the variation in leptin levels, as shown by multiple-regression analysis.

The question remains as to which factors cause the sex difference in serum leptin concentrations. The fact that this difference becomes evident at the time when sex steroids rise during puberty indicated that either stimulation by oestrogens or suppression by androgens may be involved. From various studies, including in vitro experiments with human adipocytes, there was no evidence that oestrogens would play a role. However, a significant inverse correlation between leptin levels and serum testosterone was found in healthy boys and male adolescents (Fig. 2). In contrast to many other endocrine factors, this relationship remained significant when applying multiple-regression analysis irrespective of the models used (Blum et al. 1997a). Similar findings were also obtained in obese children and adolescents (Wabitsch et al. 1997) and in obese adults (Vettor et al. 1997), suggesting that androgens, especially testosterone, suppress leptin production. This evidence was reinforced by more conclusive studies in hypogonadal men and in trans-sexual subjects. In hypogonadal men, leptin levels adjusted for BMI were elevated when compared with those for healthy men, and normalized on testosterone substitution. When testosterone levels declined, serum leptin increased again to pretreatment values (Jockenhövel et al, 1997). These changes occurred within a couple of weeks. In trans-sexuals, leptin levels reversed according to the sex steroid-induced change in the phenotype (Elbers et al. 1997). The most conclusive evidence, however, stems from in vitro experiments with human adipocytes, in which leptin production was directly suppressed by testosterone in a dose-dependent manner (Wabitsch et al. 1997).

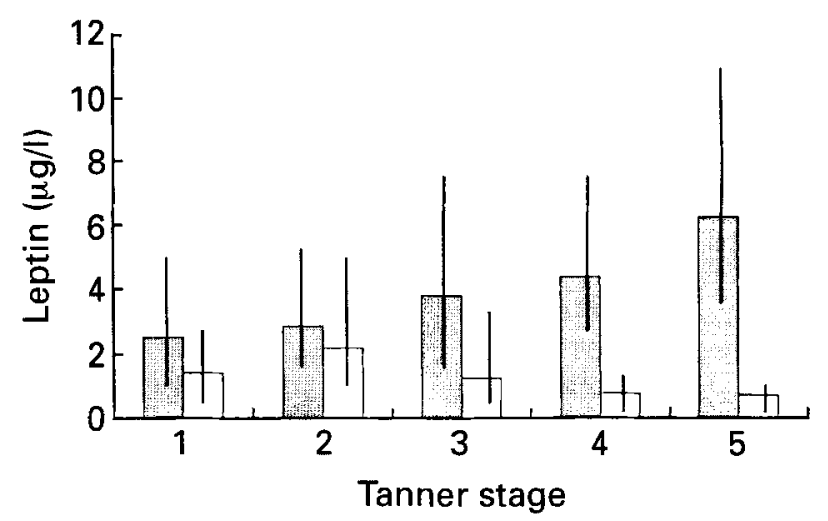

Fig. 1. Serum leptin levels in girls (중) and boys (ㅁ) at various pubertal stages. Values are medians and ranges represented by vertical bars; ranges were derived from +1 SD to -1 SD after logarithmic transformation of the leptin values.

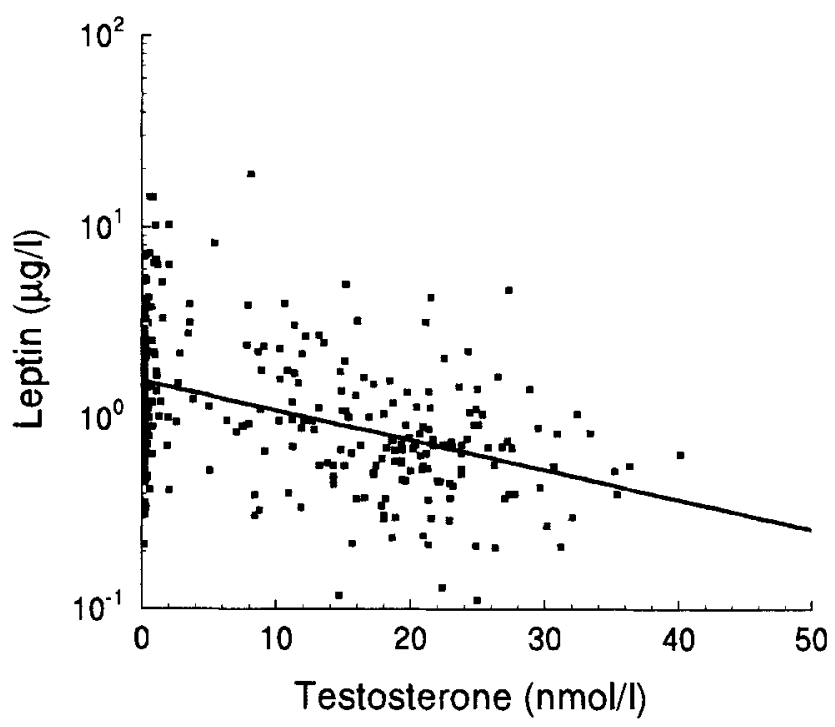

Fig. 2. Serum leptin levels in boys and male adolescents between 5 and 20 years of age $v$. testosterone levels. $n 310, r-0.43$, $P<0.0001$. 
In summary, the major regulators of serum leptin levels are body fat mass and androgen levels. Together, they determine the constitutive synthesis of leptin. Any alterations in serum leptin due to changes in either of these variables follow a slow pattern, in contrast to the relatively rapid regulation superimposed by a number of other factors (discussed later).

\section{Construction of reference ranges}

In order to decide whether a serum leptin concentration for a given patient is as expected or whether it is abnormal, reference ranges are required. These should be referred to the variable that predominantly influences leptin levels, body fat mass, and should be stratified according to sex and stage of sexual maturation. For practical reasons, the independent variable should be easily accessible. A readily-available measure of body fat is the BMI, although it is certainly not very accurate. In contrast to other more sophisticated methods, however, it provides a number of advantages: (1) it can be easily determined by everyone everywhere; (2) it does not require expensive and technically-demanding equipment; (3) it is generally retrospectively available; (4) it reflects longitudinal short-term changes in body fat quite precisely; (5) it is already widely used for defining overweight and obesity, and thus provides an accepted frame for the classification of patients.

For these reasons, leptin reference ranges were based on BMI and were stratified according to sex and stages of sexual maturation. Equations were derived which define the $90 \%$ inclusion limits of normal leptin levels (Table 1) and which allow the calculation of standard deviation scores (Z-scores) adjusting serum leptin concentrations for BMI, sex and developmental stage (Blum et al. 1997a; Blum \& Juul, 1997).

Of course, in a strict sense, these ranges are limited to the BMI ranges of the investigated cohorts. At very low or very high BMI values the relationship with leptin may deviate from the one obtained by simple mathematical extrapolation. Thus, the ranges given in Table 1 should rather be considered as 'expectation ranges'. Nevertheless, these simple mathematical tools have proved to be very useful for detection of abnormal leptin production, and revealed influences of regulators other than the major confounding variables (Table 2).

In summary, reference ranges for serum leptin levels should be referred to body fat mass, e.g. the BMI, and should be stratified according to sex and stage of sexual maturation.

\section{Short-term regulation of serum leptin}

\section{Diurnal variation}

Leptin levels exhibited a circadian variation in various groups of healthy individuals or patients with a peak at about 02.00 hours. This nocturnal peak exceeds daytime values by about $30-100 \%$ and is present in both rodents and human subjects (Sinha et al. 1996), although the rat is a night feeder and man normally eats during the day. At first sight, therefore, this increase does not appear to be related to food intake. However, during fasting the nocturnal peak was absent. Taking into account the fact that the response of leptin to insulin is much faster in rodents than in human subjects (Pagano et al. 1997), it may be concluded that the rise in leptin during the night may be induced by insulin, with a short time lag in rodents and a longer lag phase in human subjects. By cross-correlation analysis we have shown that the maximum mean insulin concentration precedes the leptin peak by $6 \mathrm{~h}$ in human subjects.

The diurnal variation in serum leptin levels suggests that serial blood sampling is required for the proper assessment of the leptin secretory status. This may, in fact, be true in specific situations (Blum et al. 1997b). For most applications, however, a single measurement in the morning or early afternoon is sufficient and informative.

\section{Food intake}

In a group of healthy adults ( $n$ 10), fasting for $3 \mathrm{~d}$ induced rapid and pronounced changes in leptin levels. After $24 \mathrm{~h}$ of complete food restriction, leptin fell to about $50 \%$ of basal levels and after $33 \mathrm{~h}$ to about $30 \%$ of the basal values, and remained stable on continuous fasting (Blum et al. 1997b). This finding compares well with reports by others in human subjects and rodents (Kolaczynski et al. 1996a; Pierroz et al. 1997). Resumption of normal eating cycles caused a rapid rise in leptin levels to almost basal values after $9 \mathrm{~h}$. Insulin

Table 1. Reference ranges of serum leptin levels referring to BMI stratified according to sex and developmental stage

(The best-fit regression lines for the various subgroups are exponential curves of the form leptin $=a^{*} e^{b * B M l}$. For sufficiently large numbers this curve corresponds to the 50th percentile. The 5th and 95th percentiles are given by the following equations: leptin $=a^{*} e^{b^{*} \mathrm{BMI}-c}$ and leptin $=e^{b^{*} B M M}+c c$ respectively. In a semi-logarithmic plot $(y$-axis $=\log$ leptin), these curves give straight lines. Accounting for the logarithmic distribution of leptin levels, the leptin standard deviation scores (SDS; Z-score) can be calculated by the following equation: leptin SDS $=\left(\ln (\right.$ leptin $\left.\left.)-\ln (a)-b^{*} B M I\right) / a\right)$

\begin{tabular}{lrcccc}
\hline Cohort & $n$ & $a$ & $b$ & $c$ & $d$ \\
\hline Males: & & & & & \\
TS 1 and 2 & 136 & 0.0146 & 0.2706 & 0.8821 & 0.5379 \\
TS 3 and 4 & 50 & 0.0181 & 0.2067 & 1.1919 & 0.6850 \\
TS 5 & 112 & 0.0316 & 0.1462 & 1.0821 & 0.6558 \\
$\quad$ Adults & 380 & 0.0130 & 0.2200 & 1.1053 & 0.6740 \\
Females: & & & & & \\
TS 1 and 2 & 136 & 0.0422 & 0.2499 & 0.7849 & 0.4786 \\
TS 3 and 4 & 43 & 0.0543 & 0.2357 & 0.5745 & 0.3379 \\
TS 5 & 157 & 0.2550 & 0.1508 & 0.7053 & 0.4301 \\
Adults & 587 & 0.3042 & 0.1467 & 0.8548 & 0.5212 \\
\hline
\end{tabular}

TS, Tanner stage; In, natural logarithm.

Table 2. Variables that control serum leptin levels

\begin{tabular}{ll}
\hline Stimulating & Suppressing \\
\hline Body fat mass & Androgens \\
Overfeeding & Fasting \\
Impaired renal function & Sympathicotonus \\
Insulin & Growth hormone \\
Glucocorticoids & Catecholamines \\
Tumour necrosis factor & Cold exposure \\
Interleukin-1 & Physical exercise \\
\hline
\end{tabular}




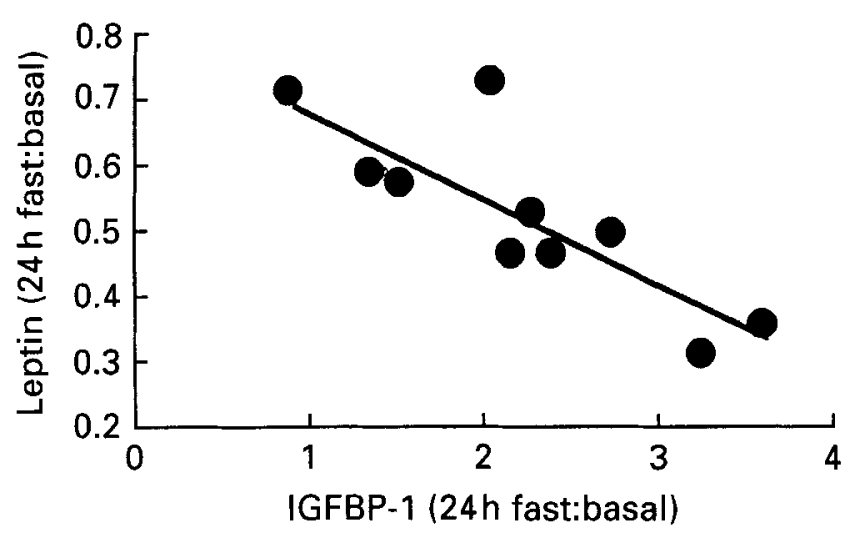

Fig. 3. Decrease in serum leptin $v$. the increase of insulin-like growth factor-binding protein (IGFBP)-1 after a $24 \mathrm{~h}$ fast in ten healthy young adults. $r-0.88, P<0.0001$. The $y$-axis represents serum leptin after fasting : non-fasted baseline value and the $x$-axis represents the corresponding ratio for IGFBP-1.

levels followed exactly the same pattern, although correlations between changes in leptin and insulin did not reach statistical significance. However, a very high inverse correlation $(r-0.88)$ was obtained between changes of leptin and insulin-like growth factor (IGF)- binding protein-1 (Fig. 3). The predominant regulator of IGF-binding protein- 1 is insulin, which has a suppressive effect. IGF-binding protein-1 is considered a surrogate marker for the activity of insulin in the liver integrated over time. It may be concluded, therefore, that insulin is the link between leptin and its regulation by food intake. In contrast to food restriction, overfeeding was shown to stimulate serum leptin levels (Harris et al. 1996; Kolaczynski et al. 1996c).

\section{Insulin}

Early studies in rodents showed that insulin stimulates leptin expression (Saladin et al. 1995). This effect became evident after only $2 \mathrm{~h}$, whereas in human subjects no changes were found within this short period (Pagano et al. 1997). This was taken as evidence at this early phase of leptin research that insulin is not involved in leptin regulation in man. Since then, however, evidence has accumulated that insulin is also an important regulator in human subjects (Kolaczynski et al 1996b; Malström et al. 1996).

In children with untreated insulin-dependent diabetes mellitus, we found significantly decreased serum leptin levels, adjusted for BMI, sex and pubertal stage (Kiess et al. 1998). On insulin therapy, levels normalized and were even elevated post puberty, which may indicate either abnormal body composition with a relative abundance of fat mass, or oversubstitution due to the intensified insulin regimen. Moreover, in a large population-based study we have shown that insulin contributed to the variation in leptin levels independently of BMI. This finding was confirmed by glucose clamp studies, which also showed that the time course of the insulin effect in human subjects is much slower than that in rodents, with no detectable increase before about $6 \mathrm{~h}$ (Malström et al. 1996). In vitro experiments with primary differentiated human adipocytes finally proved that insulin stimulates leptin expression and synthesis in a dose-dependent manner (Wabitsch et al. 1996).

\section{Glucocorticoids}

Dexamethasone administration in young healthy adults at high doses $(8 \mathrm{mg}$ ) caused a 3-fold rise in leptin levels within $9 \mathrm{~h}$ (Miell et al. 1996). A similar stimulating effect was also obtained in obese children and adults (Kiess et al. 1996) with a low dose ( $1 \mathrm{mg})$, although it was less pronounced. These findings compare well with those from animal studies (De-Vos et al. 1995) and in vitro experiments, where cortisol showed a synergistic stimulatory effect with insulin (Wabitsch et al. 1996). The fact that glucocorticoids influence leptin expression and serum leptin levels is most stringently suggested by the presence of a glucocorticoid response element in the leptin promoter region (Gong et al. 1996).

\section{Growth hormone and insulin-like growth factor-1}

In a large cohort of adult patients with growth hormone (GH) deficiency, leptin levels did not significantly deviate from the reference range when adjusted for BMI and sex. Surprisingly, however, correlations with various measures of body fat were abnormal in the sense that they were much less than those for cohorts of healthy individuals. They improved substantially on GH substitution (Attanasio et al. 1996), suggesting that $\mathrm{GH}$ is involved somehow, either directly or indirectly, in the regulation of leptin. In adolescents and young adults with GH deficiency, GH treatment caused a substantial increase in the nocturnal leptin peak during the second night after commencing substitution. Whether this effect was due to an increase in insulin or direct $\mathrm{GH}$ effects remains open. After 4 weeks of GH replacement, this increase had disappeared (Blum et al. 1997c). In children with isolated GH deficiency, BMI-, sex- and pubertal stage-adjusted leptin levels were normal before therapy and decreased by $30 \%$ after 4 weeks of GH therapy, which could not be explained by changes in body composition (Rauch et al. 1997). This finding is consistent with the suppression of leptin production to a similar degree in human adipocytes in vitro (M. Wabitsch, personal communication).

In patients with GH-receptor defect (Laron syndrome), IGF-1 treatment did not cause significant changes in leptin levels (Laron et al. 1997). This is consistent with in vitro findings in human adipocytes, in which IGF-1 stimulated leptin expression only at unphysiologically high concentrations, probably through the insulin receptor.

In summary, the influence of GH and IGF-1 on leptin levels is less clear. From our own studies we must conclude that GH exerts a short-term stimulatory effect and a long-term suppressive effect, consistent with in vitro findings. IGF-1 does not appear to influence leptin expression, in accordance with the absence of effective receptors on adipocytes.

\section{Thyroid hormones}

In large cohorts of patients with hypo- or hyperthyroidism we found no abnormal leptin levels adjusted for BMI 
and sex. Furthermore, adequate treatment correcting the disease state did not cause significant changes in leptin (Corbetta et al. 1997), although patients with a leptinreceptor defect were recently shown to have diminished thyrotropin secretion (Clément et al. 1998).

\section{Other regulating variables}

Animal and in vitro studies suggest that a number of additional variables are involved in the regulation of leptin. For example, $\beta_{3}$-adrenoceptor agonists, and other hormonal signals increasing cAMP in adipocytes, have a suppressive effect (Moinat et al. 1995; Slieker et al. 1996; Donahoo et al. 1997) which occurs through cAMP response elements on the promoter region of the $o b$ gene (Gong et al. 1996). Cytokines such as tumour necrosis factor or interleukin-1 increased leptin in animal studies and also in human subjects, which may explain the decreased food intake in sepsis (Grunfeld et al. 1996; Janik et al. 1997; Zumbach et al. 1997).

\section{Leptin: an integral component of metabolic and endocrine feedback loops}

Originally, leptin was regarded purely as a satiety signal, but this view has eventually turned out to be too narrow. A major site of leptin action is the hypothalamus, where it suppresses neuropeptide Y expression and activity (Stephens et al. 1995; Schwartz et al. 1996; Campfield \& Smith, 1998). Neuropeptide $\mathrm{Y}$ is known to be a major stimulator of appetite, and its suppression may be a main mechanism by which leptin also suppresses food intake, although a number of other mediators may also be involved. From the hypothalamus, signals are transferred to the central nervous system, which finally stimulate energy expenditure.

Interestingly, apart from its effects on energy influx and efflux, leptin was shown also to exert major effects on the various hypothalamo-pituitary-endocrine axes in rodents. Stimulation of $\mathrm{GH}$ and gonadotropins and suppression of adrenocorticotrophic hormone was reported (Ahima et al. 1996; Barash et al. 1996; Carro et al. 1997; Chehab et al. 1997; Vuagnat et al. 1998). Again, these effects may well be explained by suppression of neuropeptide Y. It should be mentioned that corresponding findings in human subjects are still unavailable at present. On the other hand, taking the regulatory influences on leptin levels of $\mathrm{GH}$, testosterone and glucocorticoids into account, these findings call for reconsideration of the various hypothalamo-pituitary-endocrine feedback loops. It appears that they should be extended by two components, neuropeptide $Y$ on one side and leptin on the other side (Fig. 4). In a simplistic view, these regulatory loops represent classical negative feedback loops which aim principally at the stabilization of a given equilibrium.

\section{Leptin in weight disorders}

Since leptin's role is that of an indicator of body fat mass, a major goal of leptin research is to delineate its importance in the pathophysiology of abnormal weight regulation such as obesity or anorexia. In the end, these efforts may help to reveal new disease entities which may be causally related to the synthesis or action of leptin.

\section{Obesity}

Most obese patients, both adults and children, have increased leptin levels (Considine et al. 1996; Ma et al. 1996; Wabitsch et al. 1997) which fall within the reference range when adjusted for sex, developmental stage and BMI (Fig. 5). This finding suggests the presence of some kind of leptin insensitivity. A number of possible mechanisms causing leptin insensitivity may be conceived, such as limited transportation capacity across the blood-brain barrier (Caro et al. 1996), a leptin-receptor defect (Clément et al. 1998), impaired post-receptor signal transduction, or even defective mechanisms further down-stream of the cascade of interactions which are involved in the regulation of balancing energy influx and efflux. However, in a small percentage of patients leptin levels were clearly lower than one would expect from their fat mass. In fact, these are mostly the patients with excessively high body weight. It may be speculated, for example, that stimulation by certain regulators such as insulin is impaired, or that leptin synthesis in adipocytes is defective. Extremely obese patients with a mutation of the leptin gene causing virtually complete absence of leptin, analogous to the $o b / o b$ mouse, have been described (Montague et al. 1997).

During dietary programmes for weight reduction, leptin levels adjusted for sex and BMI decreased further within the first couple of weeks than one would have expected from weight loss, suggesting a relative leptin deficiency in this phase. This may explain some of the problems encountered with weight-reduction programmes (Scholz et al. 1996).

In summary, it appears that at least two forms of 'normal' obesity exist, one with absolute or relative leptin deficiency and another more frequent one with relative leptin insensitivity. By analogy to diabetes mellitus, they may be classified as type 1 and type 2 obesity. Future research defining the

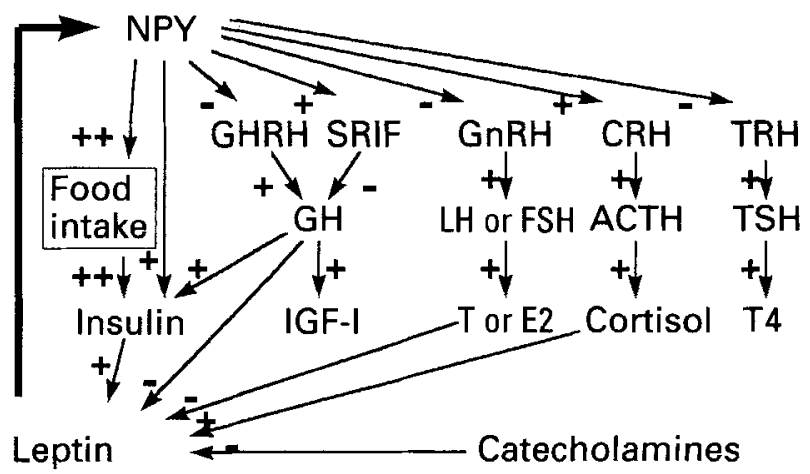

Fig. 4. Leptin and neuropeptide Y (NPY) as integral components of metabolic and endocrine feedback loops. +, Stimulation; -, suppression; GHRH, growth hormone-releasing hormone; SRIF, somatostatin; GH, growth hormone; IGF-1, insulin-like growth factor-1; GnRH, gonadotropin-releasing hormone; $\mathrm{LH}$, luteinizing hormone; $\mathrm{FSH}$, follicle-stimulating hormone; T, testosterone; E2, 17ß-oestradiol; $\mathrm{CRH}$, corticotrophin-releasing hormone; $\mathrm{ACTH}$, adrenocorticotrophic hormone; TRH, thyrotrophin-releasing hormone; TSH, thyroid-stimulating hormone; $\mathrm{T} 4$, thyroxine. 

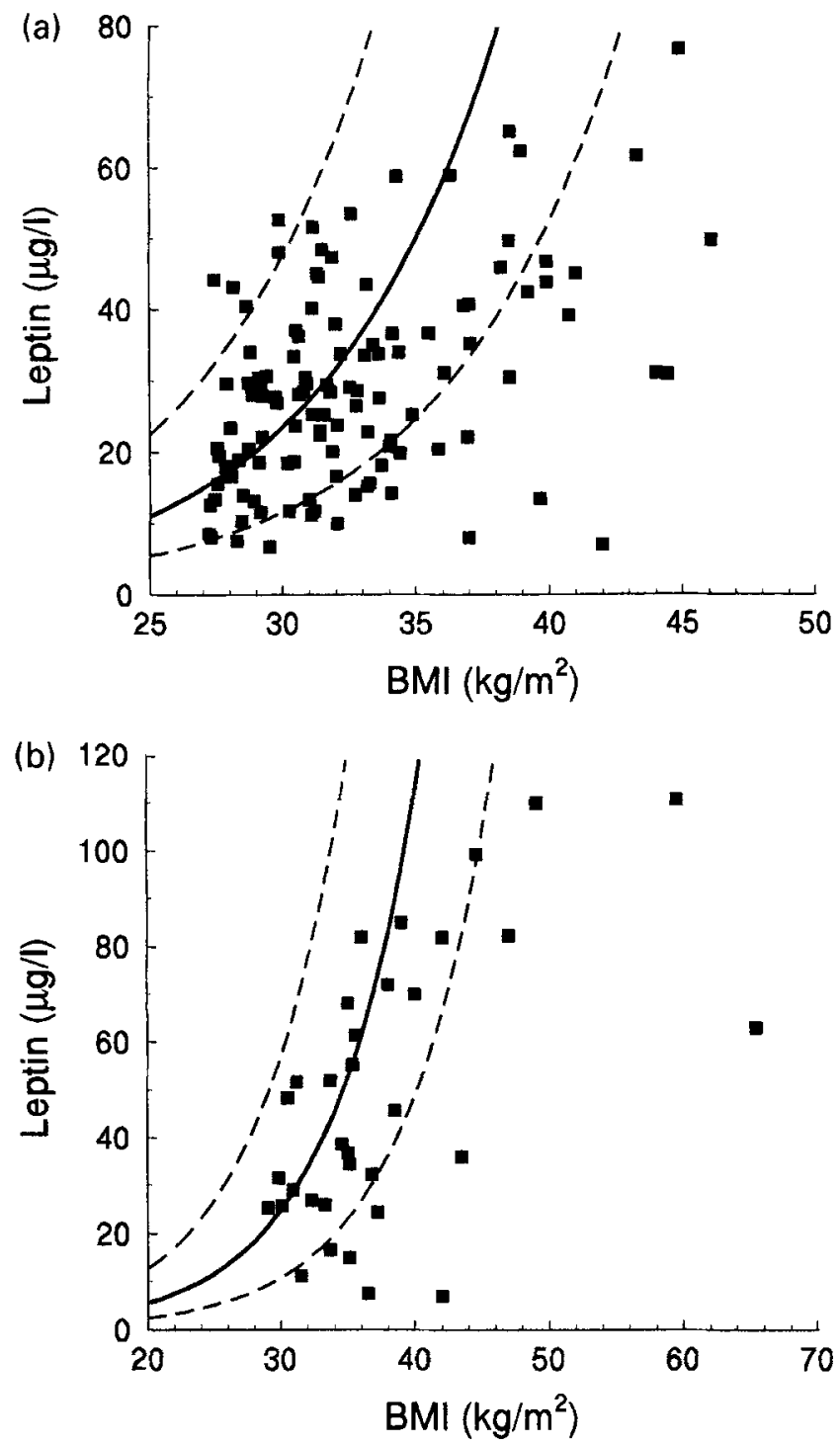

Fig. 5. Leptin levels $v$. BMl in (a) obese girls and female adolescents and (b) in obese women older than 20 years. The expectation ranges are shown for the 5th and 95th percentiles (- - -) and the 50th percentile (-).

specific molecular defects will show whether this rough classification can be refined.

We have also investigated leptin levels in a number of patients with obesity syndromes. In children with Prader-Labhardt-Willi syndrome ( $n 20)$, serum leptin was found to be elevated by 1.4 SD on average when adjusted for sex, pubertal stage and BMI. These patients suffer from a hypothalamic defect which causes abnormal eating behaviour, hypogonadism and at least partial GH deficiency. The relatively increased leptin levels may either be explained by an abnormal body composition with a relative abundance of body fat due to insufficient $\mathrm{GH}$ and gonadotropin secretion, or by the absence of a putative hypothalamic factor which exerts a negative feedback on leptin synthesis. Theoretically, this absent putative factor could be androgens due to hypogonadism. However, because most of the patients were pre-pubertal, this possibility is unlikely. Also, insulin does not seem to play a role, because insulin levels were decreased (Eiholzer et al. 1997). Overall, it appears that leptin synthesis is appropriate, but these patients have a leptin resistance due to their hypothalamic defect.

In children with Laurence-Moon-Bardet-Biedl syndrome $(n 5)$, adjusted leptin levels were in the 'expectation range' suggesting that leptin synthesis is normal. In patients with a hypothalamic defect due to radiation therapy ( $n 31)$, leptin levels were elevated compared with matched controls. This finding is particularly interesting, because it suggests the existence of a (defective) negative feedback loop from the hypothalamus back to the adipose tissue. The nature of this feedback loop is unclear at present, although it may be speculated that impaired $\mathrm{GH}$ secretion or a reduced sympathetic tone may be involved.

\section{Anorexia nervosa}

In anorectic patients leptin levels were below the reference range for age, BMI and percentage of body fat (Hebebrand et al. 1997). This finding may explain some of the characteristic symptoms of this disorder, such as reduced energy expenditure and amenorrhoea. In a cohort of females with either anorexia nervosa, bulimia or restraint eating we could quite precisely define a threshold of serum leptin concentration of $1.85 \mu \mathrm{g} / 1$, below which irregularities of menstrual cycles occurred (Köpp et al. 1997). After hospital admission and during weight gain, leptin levels started to rise rapidly when reaching a BMI threshold of about $16 \mathrm{~kg} / \mathrm{m}^{2}$ and clearly exceeded the normal range (Hebebrand et al. 1997). It may be hypothesized that this inappropriate increase causes suppression of appetite and stimulation of energy expenditure, and may thus explain the difficulty in further increasing weight (Hebebrand et al. 1997).

\section{Chronic renal failure}

A characteristic feature of children with chronic renal failure is reduced appetite. To investigate whether leptin is involved in the pathophysiology of this phenomenon, a large cohort of patients with chronic renal failure ( $n$ 124), including twenty-six patients with end-stage renal failure, was studied. A significant inverse correlation between serum leptin levels, adjusted for sex, pubertal stage and BMI, and the glomerular filtration rate was observed, suggesting that the kidneys are involved in the clearance of serum leptin. Furthermore, an inverse relationship was also obtained for adjusted leptin levels $v$. daily energy intake. It may be hypothesized, therefore, that impaired renal function causes an inappropriate increase in circulating leptin, which in turn suppresses appetite (Daschner et al. 1998).

\section{Conclusions}

The major constitutive determinants of serum leptin levels in human subjects are body fat mass and androgens. Suppression by testosterone is the most likely explanation for the well-established sex difference, with lower levels in men. Reference ranges therefore, should refer to body fat mass and should be stratified according to sex and pubertal stage. Changes in circulating leptin following variations in these 
constitutive determinants are slow and occur within several weeks. This constitutive regulation of leptin is significantly modulated by short-term regulators such as insulin or glucocorticoids; short-term in this context means several hours to $1 \mathrm{~d}$. These relatively rapid changes should be taken into account when interpreting leptin measurements in single samples.

So far, findings from clinical studies with respect to leptin regulation are consistent with animal and in vitro experiments, except that leptin variations in rodents seem to be more pronounced and more rapid. Conclusions from these experimental approaches appear, therefore, to have a high explanatory value in relation to the human situation.

In most obese patients, including those with various obesity syndromes, leptin levels are high, although they fall within the expected range according to the patient's body fat mass. In a small percentage, however, leptin levels are clearly lower than expected, suggesting the existence of partial (or in the rare extreme case, complete) leptin deficiency, which may be causally involved in the pathogenesis of fat accumulation and, potentially, endocrine derangements. Obesity, therefore, should no longer be considered a disorder per se but a symptom of distinct underlying disease entities. Clinical investigations of serum leptin may help to eventually unravel the pathophysiology of some obesity disorders. There is no doubt, however, that body-weight regulation is most complex, and that many other defects apart from abnormal leptin synthesis will be discovered in the future. Certainly, obesity research is no longer at the stage when body weight was considered only a question of 'to eat or not to eat'.

\section{References}

Ahima RS, Dushay J, Flier SN, Prabakaran D \& Flier JS (1997) Leptin accelerates the onset of puberty in normal female mice. Journal of Clinical Investigation 99, 391-395.

Ahima RS, Prabakaran D, Mantzoros C, Qu D, Lowell B, MaratosFlier E \& Flier JS (1996) Role of leptin in the neuroendocrine response to fasting. Nature 382, 250-252.

Attanasio AHF, Blum WF, Englaro P, Birkett M, Kiess W, Rascher W \& Lamberts SWJ (1996) Effect of growth hormone replacement therapy on serum leptin concentrations in adult growth hormone deficient subjects. 4th International Pituitary Congress, San Diego, p. 24 Abstr.

Barash IA, Cheung CC, Weigle DS, Ren H, Kabigting EB, Kuijper JL, Clifton DK \& Steiner RA (1996) Leptin is a metabolic signal to the reproductive system. Endocrinology 137, 3144-3147.

Blum WF, Englaro P, Hanitsch S, Juul A, Hertel NT, Skakkebaek NE, Birkett M, Heiman M, Attanasio A, Kiess W \& Rascher W (1997a) Serum leptin levels in healthy children and adolescents: dependence on body mass index, body fat mass, gender, pubertal stage and testosterone. Journal of Clinical Endocrinology and Metabolism 82, 2904-2910.

Blum WF, Englaro P, Schmitt K, Kiess W, Rascher W \& Ranke MB (1997b) Marked and rapid changes of serum leptin levels during fasting and refeeding in humans. Experimental and Clinical Endocrinology and Diabetes 105, Suppl. 1, 34 35 Abstr.

Blum WF, Jorgensen JOL, Englaro P, Heiman M, Attanasio A, Kiess W, Christiansen JS \& Rascher W (1997c) Nocturnal serum leptin increases after short-term but not during long-term treatment with growth hormone. Endocrinology and Metabolism 4, Suppl. A, 22 Abstr.
Blum WF \& Juul A (1997) Reference ranges of serum leptin levels according to body mass index, gender, and developmental stage. In Leptin - The Voice of Adipose Tissue, pp. 318-326 [WF Blum, W Kiess and W Rascher, editors]. Heidelberg: J.A. Barth Verlag.

Campfield LA \& Smith FJ (1998) Overview: neurobiology of OB protein (leptin). Proceedings of the Nutrition Society 57, $429-440$.

Caro JF, Kolaczynski JW, Nyce MR, Ohannesian JP, Opentanova I, Goldman WH, Lynn RB, Zhang PL, Sinha MK \& Considine RV (1996) Decreased cerebrospinal-fluid/serum leptin ratio in obesity: a possible mechanism for leptin resistance. Lancet 348, 159-161.

Carro E, Senaris R, Considine RV, Casanueva FF \& Dieguez C (1997) Regulation of in vivo growth hormone secretion by leptin. Endocrinology 138, 2203-2205.

Chehab FF, Lim ME \& Lu R (1996) Correction of the sterility defect in homozygous obese female mice by treatment with the human recombinant leptin. Nature Genetics 12, 318-320.

Chehab FF, Mounzih K, Lu R \& Lim ME (1997) Early onset of reproductive function in normal female mice treated with leptin. Science 275, 88-90.

Cheung CC, Thornton JE, Kuijper JL, Weigle DS, Clifton DK \& Steiner RA (1997) Leptin is a metabolic gate for the onset of puberty in the female rat. Endocrinology 138, 855-858.

Clayton PE, Gill MS, Hall CM, Tillmann V, Whatmore AJ \& Price DA (1997) Serum leptin through childhood and adolescence. Clinical Endocrinology 46, 727-733.

Clément K, Vaisse C, Lahlou N, Cabrol S, Pelloux V, Cassuto D, Gourmelen M, Dina C, Chambaz J, Lacorte J-M, Basdevant A, Bougnères P, Lebouc Y, Froguel P \& Guy-Grand B (1998) A mutation in the human leptin receptor gene causes obesity and pituitary dysfunction. Nature 392, 398-401.

Coleman DL \& Hummel KP (1969) Effects of parabiosis of normal with genetically diabetic mice. American Journal of Physiology 217, 1298-1304.

Considine RV, Sinha MK, Heiman ML, Kriauciunas A, Stephens TW, Nyce MR, Ohannesian JP, Marco CC, McKee LJ, Bauer TL \& Caro JF (1996) Serum immunoreactive-leptin concentrations in normal-weight and obese humans. New England Journal of Medicine 334, 292-295.

Corbetta S, Englaro P, Giambona S, Persani L, Blum WF \& BeckPeccoz P (1997) Lack of effects of circulating thyroid hormone levels on serum leptin concentrations. European Journal of Endocrinology 137, 659-663.

Daschner M, Tönshoff B, Blum WF, Englaro P, Wingen A-M, Schaefer F, Rascher W \& Mehls O (1998) Inappropriate elevation of serum leptin levels in children with chronic renal failure. Journal of the American Society of Nephrology (In the Press).

De-Vos P, Saladin R, Auwerx J \& Staels B (1995) Induction of ob gene expression by corticosteroids is accompanied by body weight loss and reduced food intake. Journal of Biological Chemistry 270, 15958-15961.

Donahoo WT, Jensen DR, Yost TJ \& Eckel RH (1997) Isoproterenol and somatostatin decrease plasma leptin in humans: a novel mechanism regulating leptin secretion. Journal of Clinical Endocrinology and Metabolism 82, 4139-4143.

Eiholzer U, Gisin R, Englaro P, Blum WF, Rascher W, Steinert H, Torresani T \& Prader A (1997) Fat mass and plasma concentrations of leptin, insulin, IGF-I and IGF-binding proteins in Prader-Willi syndrome. Hormone Research 48, Suppl. 2, 51 Abstr.

Elbers JMH, Asscheman H, Seidell JC, Frölich M, Meinders AE \& Gooren LJG (1997) Reversal of the sex difference in serum leptin levels upon cross-sex hormone administration in transsexuals. Journal of Clinical Endocrinology and Metabolism 82, $3267-3270$. 
Frederich RC, Hamann A, Anderson S, Lollmann B, Lowell BB \& Flier JS (1995) Leptin levels reflect body lipid content in mice: evidence for diet-induced resistance to leptin action. Nature Medicine 1, 1311-1314.

Frisch RE (1980) Pubertal adipose tissue: is it necessary for normal sexual maturation? Federation Proceedings 39, 2395-2400.

Gong DW, Bi S, Pratley RE \& Weintraub BD (1996) Genomic structure and promoter analysis of the human obese gene. Journal of Biological Chemistry 271, 3971-3974.

Grunfeld C, Zhao C, Fuller J, Pollack A, Moser A, Friedman J \& Feingold KR (1996) Endotoxin and cytokines induce expression of leptin, the ob gene product, in hamsters. Journal of Clinical Investigation 97, 2152-2157.

Halaas JL, Gajiwala KS, Maffei M, Cohen SL, Chait BT, Rabinowitz D, Lallone RL, Burley SK \& Friedman JM (1995) Weightreducing effects of the plasma protein encoded by the obese gene. Science 269, 543-546.

Harris RB, Ramsay TG, Smith SR \& Bruch RC (1996) Early and late stimulation of ob mRNA expression in meal-fed and overfed rats. Journal of Clinical Investigation 97, 2020-2026.

Hausberger FX (1958) Parabiosis and transplantation experiments in hereditarily obese mice. Anatomical Record 130, 313.

Hebebrand J, Blum WF, Barth N, Coners H, Englaro P, Juul A, Ziegler A, Warnke A, Rascher W \& Remschmidt H (1997) Leptin levels in patients with anorexia nervosa are reduced in the acute stage and elevated upon short-term weight restoration. Molecular Psychiatry 2, 330-334.

Hervey GR (1959) The effects of lesions in the hypothalamus in parabiotic rats. Journal of Physiology 145, 336-352.

Hickey MS, Israel RG, Gardiner SN, Considine RV, McCammon MR, Tyndall GL, Houmard JA, Marks RHL \& Caro JF (1996) Gender difference in serum leptin levels in humans. Biochemical and Molecular Medicine 59, 1-6.

Horn R, Geldszus R, Pötter E, von zur Mühlen A \& Brabant G (1996) Radioimmunoassay for the detection of leptin in human serum. Experimental and Clinical Endocrinology and Diabetes 104, $454-458$.

Janik JE, Curti BD, Considine RV, Rager HC, Powers GC, Alvord WG, Smith JW II, Gause BL \& Kopp WC (1997) Interleukin lalpha increases serum leptin concentrations in humans. Journal of Clinical Endocrinology and Metabolism 82, 3084-3086.

Jockenhövel F, Blum WF, Vogel E, Englaro P, Müller-Wieland D, Reinwein D, Rascher W \& Krone W (1997) Testosterone substitution normalizes elevated leptin serum levels in hypogonadal men. Journal of Clinical Endocrinology and Metabolism 82, 2510-2513.

Kennedy GC (1953) The role of depot fat in the hypothalamic control of food intake in the rat. Proceedings of the Royal Society 140, 578-592.

Kiess W, Anil M, Blum WF, Englaro P, Juul A, Attanasio A, Dötsch J \& Rascher W (1998) Serum leptin levels in children and adolescents with insulin-dependent diabetes mellitus in relation to metabolic control and body mass index. European Journal of Endocrinology 138, 501-509.

Kiess W, Englaro P, Hanitsch S, Rascher W, Attanasio A \& Blum WF (1996) High leptin concentrations in serum of very obese children are further stimulated by dexamethasone. Hormone and Metabolic Research 28, 708-710.

Kolaczynski JW, Considine RV, Ohannesian J, Marco C, Opentanova I, Nyce MR, Myint M \& Caro JF (1996a) Responses of leptin to short-term fasting and refeeding in humans: A link with ketogenesis but not ketones themselves. Diabetes $\mathbf{4 5}$, 1511-1515.

Kolaczynski JW, Nyce MR, Considine RV, Boden G, Nolan JJ, Henry R, Mudaliar SR, Olefsky J \& Caro JF (1996b) Acute and chronic effects of insulin on leptin production in humans: studies in vivo and in vitro. Diabetes 45, 699-701.

Kolaczynski JW, Ohannesian J, Considine RV, Marco C \& Caro JF (1996c) Response of leptin to short-term and prolonged overfeeding in humans. Journal of Clinical Endocrinology and Metabolism 91, 4162-4165.

Köpp W, Blum WF, von Prittwitz S, Ziegler A, Lübbert H, Emons G, Herzog W, Herpertz S, Deter H-C, Remschmidt H \& Hebebrand J (1997) Low leptin levels predict amenorrhea in underweight and eating disordered females. Molecular Psychiatry 2 , 335-340.

Laron Z, Silbergeld A \& Blum WF (1997) Serum leptin levels in untreated and IGF-I treated patients with Laron syndrome. 79th Annual Meeting of the Endocrine Society, Minneapolis, p. 471 Abstr.

Ma Z, Gingerich RL, Santiago JV, Klein S, Smith CH \& Landt M (1996) Radioimmunoassay of leptin in human plasma. Clinical Chemistry 42, 942-946.

Maffei M, Halaas J, Ravussin E, Pratley RE, Lee GH, Zhang Y, Fei H, Kim S, Lallone R, Ranganathan S, Kern PA \& Friedman JM (1995) Leptin levels in human and rodent: measurement of plasma leptin and ob RNA in obese and weight-reduced subjects. Nature Medicine 1, 1155-1161.

Malström R, Taskinen M-R, Karonen S-L \& Yki-Järvinen H (1996) Insulin increases plasma leptin concentrations in normal subjects and patients with NIDDM. Diabetologia 39, 993-996.

Mantzoros CS, Flier JS \& Rogol AD (1997) A longitudinal assessment of hormonal and physical alterations during normal puberty in boys. V. Rising leptin levels may signal the onset of puberty. Journal of Clinical Endocrinology and Metabolism 82, 1066-1070.

Miell JP, Englaro P \& Blum WF (1996) Dexamethasone induces an acute and sustained rise in circulating leptin levels in normal human subjects. Hormone and Metabolic Research 28, 704-707.

Moinat M, Deng C, Muzzin P, Assimacopoulos-Jeannet F, Seydoux J, Dulloo AG \& Giacobino JP (1995) Modulation of obese gene expression in rat brown and white adipose tissues. FEBS Letters 373, 131-134.

Montague CT, Farooqi IS, Whitehead JP, Soos MA, Rau H, Wareham NJ, Sewter CP, Digby JE, Mohammedi SN, Hurst JA, Cheetham CH, Earley AR, Barnett AH, Prins JB \& O'Rahilly S (1997) Congenital leptin deficiency is associated with severe early-onset obesity in humans. Nature 387, 903-908.

Pagano C, Macor C, Englaro P, Granzotto M, Rella E, Novo F, Sagrillo E, Blum WF \& Vettor $R$ ( 1997) Does insulin regulate leptin? Studies in rats and humans. In Leptin - The Voice of Adipose Tissue, pp. 83-92 [WF Blum, W Kiess and W Rascher, editors]. Heidelberg: J.A. Barth Verlag.

Pierroz DD, Heritier A, Lalaoui M, d'Allèves V, Blum WF \& Aubert ML (1997) Leptin is a metabolic signal for sexual function: reciprocal changes in plasma leptin and arcuate nucleus NPY mRNA in two models with adverse metabolic conditions with hypogonadism. 79th Annual Meeting of the Endocrine Society, Minneapolis, p. 99 Abstr.

Rauch F, Westermann F, Englaro P, Blum WF \& Schönau E (1997) Serum leptin during growth hormone therapy in growth hormone deficient children. Hormone Research 48, Suppl. 2, 55 Abstr.

Saad MF, Damani S, Gingerich RL, Riad-Gabriel MG, Khan A, Boyadjiani R, Jinagouda. SD, El-Tawil K, Rude RK \& Kamdar V (1997) Sexual dimorphism in plasma leptin concentration. Journal of Clinical Endocrinology and Metabolism 82, 579-584.

Saladin R, De-Vos P, Guerre-Millo M, Leturque A, Girard J, Staels B \& Auwerx J (1995) Transient increase in obese gene expression after food intake or insulin administration. Nature 377 , 527-529. 
Scholz GH, Englaro P, Thiele I, Scholz M, Klusman T, Kellner K, Rascher W \& Blum WF (1996) Dissociation of serum leptin concentration and body fat content during long term dietary intervention in obese individuals. Hormone and Metabolic Research 28, 718-723.

Schwartz MW, Seeley RJ, Campfield LA, Bum P \& Baskin DG (1996) Identification of targets of leptin action in rat hypothalamus. Journal of Clinical Investigation 98, 1101-1106.

Sinha MK, Ohannesian JP, Heiman ML, Kriauciunas A, Stephens TW, Magosin S, Marco C \& Caro JF (1996) Nocturnal rise of leptin in lean, obese, and non-insulin-dependent diabetes mellitus subjects. Journal of Clinical Investigation 97, 1344-1347.

Slieker LJ, Sloop KW, Surface PL, Kriauciunas A, LaQuier F, Manetta J, Bue-Valleskey J \& Stephens TW (1996) Regulation of expression of ob mRNA and protein by glucocorticoids and cAMP. Journal of Biological Chemistry 271, 5301-5304.

Stephens TW, Basinski M, Bristow PK, Bue-Valleskey JM, Burgett SG, Craft L, Hale J, Hoffmann J, Hsiung HM, Kriauciunas A, MacKeller W, Rosteck PR, Schöner B, Smith D, Tinsley FC, Zhang YY \& Heiman M (1995) The role of neuropeptide Y in the antiobesity action of the obese gene product. Nature 377, 530-532.

Tanner JM \& Whitehouse RH (1976) Clinical longitudinal standards for height, weight, height velocity, weight velocity and stages of puberty. Archives of Disease in Childhood 51, 170-179.
Vettor R, De Pergola G, Pagano C, Englaro P, Laudadio E, Giorgino F, Blum WF, Giorgino R \& Federspil G (1997) Relationship between serum leptin and testosterone in obese men. In LeptinThe Voice of Adipose Tissue, pp. 237-245 [WF Blum, W Kiess and W Rascher, editors]. Heidelberg: J.A. Barth Verlag.

Vuagnat BAM, Pierroz DD, Lalaoui M, Englaro P, Pralong FP, Blum WF \& Aubert ML (1998) Evidence for a leptinneuropeptide $\mathrm{Y}$ axis for the regulation of growth hormone secretion in the rat. Neuroendocrinology 67, 291-300.

Wabitsch M, Blum WF, Muche R, Braun M, Hube F, Rascher W, Heinze E, Teller W \& Hauner H (1997) Contribution of androgens to the gender difference in leptin production in obese children and adolescents. Journal of Clinical Investigation 100 , 808-813.

Wabitsch M, Jensen PB, Blum WF, Christoffersen CT, Englaro P, Heinze E, Rascher W, Teller W, Tornqvist H \& Hauner H (1996) Insulin and cortisol promote leptin production in cultured human fat cells. Diabetes 45, 1435-1438.

Zhang Y, Proenca R, Maffei M, Barone M, Leopold L \& Friedman JM (1994) Positional cloning of the mouse obese gene and its human homologue. Nature 372, 425-432.

Zumbach MS, Boehme MWJ, Wahl P, Stremmel W, Ziegler R \& Nawroth PP (1997) Tumor necrosis factor increases serum leptin levels in humans. Journal of Clinical Endocrinology and Metabolism 82, 4080-4082. 